\title{
Application of $\mathrm{TiO}_{2} / \mathrm{Fe}_{3} \mathrm{O}_{4} / \mathrm{MWCNTs}$ Nanocomposite Conductive Mediator for Fabrication of Kojic Acid Sensor
}

\author{
Peyman Mohammadzadeh Jahani ${ }^{1, *}$, Maedeh Jafari $^{2}$, Vinod Kumar Gupta ${ }^{3, *}$, Shilpi Agarwal $^{3}$ \\ ${ }^{1}$ School of Medicine, Bam University of Medical Sciences, Bam, Iran \\ ${ }^{2}$ Department of Pediatrics, School of Medicine, Kerman University of Medical Sciences, Kerman, Iran \\ ${ }^{3}$ Center of Excellence for Advanced materials Research King Abdulaziz University, Jeddah, Saudi \\ Arabia \\ *E-mail: peymanjahani1234@gmail.com, vinodfcy@gmail.com
}

doi: $10.20964 / 2020.06 .89$

Received: 29 February 2020 / Accepted: 21 April 2020 / Published: 10 May 2020

\begin{abstract}
This research work focused on kojic acid determination using carbon-paste electrode (CPE) improved with $\mathrm{TiO}_{2} / \mathrm{Fe}_{3} \mathrm{O}_{4} / \mathrm{MWCNTs}$ nanocomposite and ionic liquid $\left(\mathrm{TiO}_{2} / \mathrm{Fe}_{3} \mathrm{O}_{4} / \mathrm{MWCNTs} / \mathrm{IL}-\mathrm{CPE}\right)$. Redox behavior of kojic acid as an antioxidant food additive was examined by different electrochemical techniques. The recording results confirmed $\mathrm{TiO}_{2} / \mathrm{Fe}_{3} \mathrm{O}_{4} / \mathrm{MWCNTs} / \mathrm{IL}-\mathrm{CPE}$ could improve redox behavior of kojic acid in current and potential cases. The $\mathrm{TiO}_{2} / \mathrm{Fe}_{3} \mathrm{O}_{4} / \mathrm{MWCNTs} / \mathrm{IL}-\mathrm{CPE}$ showed linear relation with kojic acid concentration in the range $0.5 \mu \mathrm{M}-300.0 \mu \mathrm{M}$ with detection limit $0.2 \mu \mathrm{M}$ using the DPV. The $\mathrm{TiO}_{2} / \mathrm{Fe}_{3} \mathrm{O}_{4} / \mathrm{MWCNTs} / \mathrm{IL}-\mathrm{CPE}$ was used to determine kojic acid in real food samples.
\end{abstract}

Keywords: Kojic acid, Carbon amplified sensor, $\mathrm{TiO}_{2} / \mathrm{Fe}_{3} \mathrm{O}_{4} / \mathrm{MWCNTs}$ nanocomposite, Ionic liquid

\section{FULL TEXT}

(C) 2020 The Authors. Published by ESG (www.electrochemsci.org). This article is an open access article distributed under the terms and conditions of the Creative Commons Attribution license (http://creativecommons.org/licenses/by/4.0/). 